\title{
Exploring Students' Speaking Anxiety Factors in an Online EFL Classroom
}

\author{
Iman Nugroho \\ iman.nugroho17008@student.unsika.ac.id \\ Fauzi Miftakh \\ fauzi.miftakh@unsika.ac.id \\ Yuna Tresna Wahyuna \\ yuna.tresna@fkip.unsika.ac.id \\ Universitas Singaperbangsa Karawang
}

\begin{abstract}
Due to pandemic covid-19, the learning setting has changed from face-to-face to an online learning environment to prevent the further spread of infection. This change mostly affected the state of psychological, specifically anxiety issues. Specific anxiety called Foreign Language Anxiety (FLA) appears as anxiety affiliates with foreign language learning. Despite foreign language anxiety is evidenced to be hinder students' achievements, there are only a few studies that have explored FLA in an online setting. Therefore, by using a case study, this research paper tried to investigate the factors of speaking anxiety of 5 students from different anxiety levels. These students were selected from a total of 30 students using the Foreign Language Anxiety Scale (FLCAS), which later be interviewed and asked to write a reflective journal. The result showed that some sources of each categorical factor (communication apprehension, test anxiety, fear of negative evaluation) can be classified as inter-lingual or intra-lingual factors. Moreover, some sources of factors have developed to new manifestations due to learning setting' shifting. Additionally, as a part of communication apprehension, teachers' bad teaching habits appeared as the most common factor to arise students' speaking anxiety. Therefore, this study suggests teachers to evaluate their teaching habits, to reduce the influence of bad teaching habits on the students' speaking anxiety.
\end{abstract}

Keywords: Face-to-Face; FLA; Online Learning

\section{INTRODUCTION}

During the pandemic Covid-19 outbreak, online learning setting has been becoming a phenomenon in many countries to protect national health, including in Indonesia. The use online learning setting is favourable since it provides more flexibility to access the content and the instruction from anywhere (Yulia, 2020). Unfortunately, since the environmental setting has changed, many aspects of language learning have also been affected. Specifically, one of many important aspects that are most affected is in the scope of psychological (Irawan, Dwisona, \& Lestari, 2020). 
According to Irawan, Dwisona, \& Lestari (2020), some various progressive steps of the adjustment in education to reduce the spread of Covid-19 have resulted psychological effects for students, such as symptoms of moderate to severe depression, stress levels, and anxiety.

In specific to anxiety, huge effects on many language learning aspects might be influenced by it (Horwitz, Horwitz, \& Cope, 1986). Moreover, as anxiety is affiliated with foreign language learning, it may destructively affect students' learning process as well as the outcome of their language achievement. This affiliation is widely known as Foreign Language Anxiety (FLA). Generally, refers to foreign language anxiety theory developed by Horwitz, et al. (1986), there are three pertinent components of FLA: communication apprehension, fear of negative evaluation, and test anxiety. They defined communication apprehension as "a type of shyness characterized by fear of or anxiety about communicating with people". Fear of negative evaluation implies "apprehension about others' evaluation, avoidance of evaluative situation, and the expectation that others would evaluate oneself negatively". And the last, test anxiety which consists of foreign language tests as well as examination means "a type of performance anxiety stemming from a fear of failure".

Nonetheless, the sources of FLA in online learning might whether be similar to the conventional learning setting, or they appear as new manifestations. Yaniafari \& Rihardini (2021) found that the most mentioned source of anxiety in an online class was fear of negative evaluation for being laughed at and being judged for making mistakes in which is similar to the traditional setting. Therefore, the anonymity that online learning offered made students felt benefited (Pichette, 2009). On the other hand, as a new manifestation of source, Kaisar \& Chowdhury (2020) found that fear of being disconnected was the most mentioned reason for speaking anxiety of the students.

It's important to investigate more various sources of anxiety in online learning to look for the best anticipation of the bad effects, knowing a lot of prior researches in exploring foreign language anxiety were mainly focused on traditional classroom setting (Bollinger, 2017, and Majid, Sharil, Luaran, \& Nadzri, 2012). Therefore, for the necessity of further investigation in the case of the online classroom setting, this paper tried to unearth the factors that arise anxiousness of 5 students from 5 different anxiety levels in an online EFL classroom.

\section{LITERATURE REVIEW}

\section{Previous Related Study}

Grant, Huang, \& Pasfield-Neofitou (2013) examined whether learners of Monash University feel less FLA in online multiuser 3D virtual world simulation than in the face-to-face learning environment. It said that in both face-to-face and virtual learning there were multiple factors of FLA, and these factors were similar between virtual and face-to-face learning environments. Moreover, in terms of language use, the virtual environment was considered less stressful by students. In contrast, Kaisar 
\& Chowdhury (2020) in their mixed-method study implied that online learning has its version of factors of FLA. Using their self-made version of anxiety scale called Foreign Language Virtual Classroom Anxiety Scale (FLVCAS) they were exploring learners' FLA. In general, the objective of this study was to investigate whether FLA is healed or added any features by the virtual learning environment. Yaniafari \& Rihardini in 2021 conducted survey research. By investigating students' speaking anxiety in two different learning settings, they tried to reveal whether online learning settings helped to reduce students' anxiety levels or not. 120 students who have experienced both learning settings were surveyed. This study found that generally, online speaking classes succeed to reduce students' anxiety $(48,41 \%)$ compared with f2f learning settings $(60,96 \%)$.

\section{The Theory of the Variable}

\section{Foreign Language Anxiety}

Many people with a good ability in learning a particular subject, highly motivated, and admiring native speakers of the target language, often claim themselves to have a mental block in foreign language learning, and one of the reasons might prevent them from achieving their learning goal is anxiety. Foreign language anxiety is conceived by Horwitz, Horwitz, \& Cope (1986) as "a distinct complex of selfperceptions, beliefs, feelings, and behaviors related to classroom language learning arising from the uniqueness of the language learning process". Later, they suggested this happens when people cannot fulfill their self-made assumption of being a good communicator in a foreign language as good as in their mother language. As it happens, they might feel reticent, shy, afraid, or even panic. Moreover, vocabulary deficit was mentioned harmed students spoken target language, which also supported by Akkakoson (2016) in his research's findings claimed that the primary source of speaking anxiety is the lack of students' vocabulary repertoire.

Furthermore, Horwitz, Horwitz, \& Cope (1986) also mentioned that students who are anxious about foreign language learning perform avoidance behavior, such as avoiding studying by skipping class as well as postponing homework to relieve anxiety, freezing during a presentation, collecting courage to enter the class by standing outside the door, and going blank before the test starts. Thus, it can be said that the most common strategy to diminish anxiety in speaking by highly anxious students is resignation (Yasuda \& Nabei, 2018).

\section{Factors of Foreign Language Anxiety}

Foreign language anxiety generally has an association with different factors which commonly can be classified as internal and external factors. However, researchers 
have their terms to represent those two distinct factors, McIntyre \& Gardner (1991), defined them as general and communicative anxiety, while (Daud, Ras, Novitri, \& Audia, 2019) labeled them as social, linguistic, and personal factors, also Chou (2018) labeled them as students' variable and situational variable. It can simply describe that students' personalities, beliefs, and attitudes within foreign language learning generate the personal/intra-lingual/students' variables determinants of FLA. In contrast, the external/situational factors centered on the inter-personal interactions (learner-teacher or learner-learner) during the language learning process.

In particular, Horwitz, Horwitz, \& Cope (1986) established three related situationspecific performance anxieties which are communication apprehension, test anxiety, and fear of negative evaluation. Communication apprehension is defined by them as a type of nervousness characterized by the anxiety to communicate with people due to constantly monitored and lack of situational communicative control as well as personal knowledge as it influences the ability someone to make ones understand as well as understanding others' speeches. The second factor is test anxiety, which produces the fear of failing to perform. It can be described by how the students consider a high demand of putting themselves on perfect mastery of foreign language, and when they cannot achieve that, they considered it as a failure. Akkakoson (2016) in his research claimed that test anxiety became the most frequent factor to appear than communicative apprehension. Afterward, fear of negative evaluation is explained as students' fear of others' evaluation toward their performances. Anxious students tend to have attention divided if they exaggeratedly centered their concern on negative evaluation of others, "instead of receiving information, their attention is drained as they try to find a solution that reduces people's negative evaluations, which are unrelated to their language task" (Abdurahman \& Rizqi, 2020). It happens as the result of dread of getting a low score on the task, as they consider that academic score will affect their future (Naudhani, Wu, \& Naudhani, 2018).

\section{Online Learning: Anxiety Creator or Healer}

According to Pichette, (2009), there were several favored common reasons for students choosing online learning, those are "online learning" which is the most common thing in their places, time flexibility, the cost, life roles, difficulty in commuting, disability, and personal reason. In specific for foreign language anxiety, he later mentioned that since students with anxiety are reluctant to engage with their peers in offline classes, they tend to choose online learning because it provides anonymity so they don't have to interact with their peers. From his 
statement, it can be concluded that high-level anxiety student was less stressful in the online environment.

In contrast, Kaisar \& Chowdhury (2020) through in-depth interviews found that nine out of twelve students agreed that the online learning environment provoked their anxiety. It could be possible since they were afraid of not having the best outcome of language learning achievement. Compared with Pichette (2009) which mentioned that anxious students were benefited from anonymity in online learning, the participant of Kaisar \& Chowdhury (2020) constantly mentioned that since online learning is dominated by the teacher, lack of students' presence in online learning decreased their opportunities for interaction, and made the class boring, unbeneficial, and uncomfortable, so that is why they were afraid if their language learning achievements would decrease. Unfortunately for this contradiction, it is unclear which level of anxiety students are that Kaisar \& Chowdhury (2020) claimed to have anxiety in online learning.

\section{METHOD}

\section{Design and Samples}

This research is a case study. The most important consideration was influenced by the reason that a great detail of the teaching and learning process can be described by this design (Crooker, 2009 as cited in Heigham \& Croker, 2009). Specifically, the site and participants were selected based on the form of convenience sampling in which the members of sampling are chosen for study based on practical criteria such as accessibility easiness, geographical proximity, the flexibility of time needed, or willingness to participate (Etikan, 2016). By the means, the research was carried out at SMK Negeri 1 Banyumas in the first semester of the academic year of $2021 / 2022$. The research was conducted for five days started on July $14^{\text {th }}$. The school is located in Banyumas, Central Java, Indonesia. The researcher gathers 30 students of eleventh grade as participants to measure their anxiety levels. Afterward, the participants were eliminated to find the five students as representative for each level of anxiety, which is very anxious, anxious, mildly anxious, relaxed, and very relaxed.

\section{Instrument and Procedure}

The first instrument is Foreign Language Classroom Anxiety Scale. Horwitz, Horwitz, \& Cope's (1986) Foreign Language Classroom Anxiety Scale (FLCAS) consist of 33 questions divided into two different types of statement, those were "positive" and "negative" statements. Each type of statement was key-reversed before scoring, which means that a low score for each positive item represents a low level of anxiety, and a high score for each negative item represents a high level of anxiety. The questions were sequenced using Liker Scaling developed by MacIntyre and Garder (1994b). The negative statement was ranging from 5-1 score points for each answer, which is "Strongly Agree", "Agree", "Neutral", "Disagree", 
and "Strongly Disagree" (MacIntyre and Gardner, 1994b). The positive statement was ranging from 1-5 score points for each answer consisting of "Strongly Agree", "Agree", "Neutral", "Disagree", and "Strongly Disagree".

After five representative participants were chosen using FLCAS, they began to be interviewed. The in-depth interview is used and focused on the personal factors of each representative participant of each anxiety level, and tried to dive deeper for every answer they gave using impromptu questions as much as possible until detailed information was gained. It should be done based on the nature of an indepth interview in which questions are not pre-determined (Richards as cited in Heigham \& Croker, 2009). The basic questions were about what kind of situations that anxiety is most likely to appear, why that situation influences their speaking anxiety, what kind of anxiety symptoms they faced, what strategies they usually perform to reduce their speaking anxiety, and why they used that kind of strategies.

Finally, a reflective journal was used to confirm the obtained information as well as to get additional information that the researcher didn't get in the interview section. The students should have made a reflective journal right after the lesson ended. In students' self-reflective journals, they should have mentioned their experience of facing a particular situation that made them felt pressured, what part of the recent lesson triggered their anxiety in speaking, the reason for it, and how they overcame the anxiety at that time as well as in the future. On other hand, since reflective journals are way more informal in writing areas, students could have added some elements into it, such as "short post-it note memos or reminders, or visuals such as photographs, drawings, sketches, diagrams, maps, or illustrative samples of students' work" (Burns as cited in Heigham \& Croker, 2009)

\section{Data Analysis}

The analysis data of FLCAS begin with statements calculation and categorization to determine students' anxiety levels. The data categorization from the result of FLCAS was adopted from Oetting's Scale (1983) which consists of "Very Anxious", "Anxious", "Mildly Anxious", "Relaxed", and "Very Relaxed". In detail, the ranges of the score for each category are listed in the table below:

Table 1. FLCAS Anxiety Scoring and Categorization
\begin{tabular}{|l|l|}
\hline Range & \multicolumn{1}{c}{ Level } \\
\hline $124-165$ & Very Anxious \\
\hline $108-123$ & Anxious \\
\hline $87-107$ & Mildly Anxious \\
\hline $66-86$ & Relaxed \\
\hline $33-65$ & Very Relaxed \\
\hline
\end{tabular}

(Oetting, 1983 as cited in Daud, Ras, Novitri, \& Audia, 2019) 
Table 2. Five Representatives of Five Anxiety Levels

\begin{tabular}{|l|l|c|c|}
\hline No. & $\begin{array}{c}\text { Name } \\
\text { (Pseudonyms) }\end{array}$ & Anxiety Level & $\begin{array}{c}\text { Anxiety } \\
\text { Level's } \\
\text { Code }\end{array}$ \\
\hline 1. & Qonitah & Very Relaxed & VR \\
\hline 2. & Dhifa & Relaxed & R \\
\hline 3. & Rina & Mildly Anxious & MA \\
\hline 4. & Intan & Anxious & A \\
\hline 5. & Dwi & Very Anxious & VA \\
\hline
\end{tabular}

Furthermore, the data gained from interviews and reflective journals were analyzed using analysis that was adapted from Braun \& Clarke's (2006) thematic data analysis and later is added one more step that the researcher considered as important to do. Specifically, the steps of analysis of the data or data organization and interpreting consist of familiarizing with the data generate initial codes, searching for themes, classify the themes to emerging themes, review the themes, define and name the themes, and finally produce the report

\section{RESULT AND DISCUSSION}

\section{The Role of Intra-Lingual Factors on Arising Students' Speaking Anxiety in Online EFL Classroom}

\section{Communication Apprehension}

In the scope of intra-lingual, from a total of 5 students who suffered communication apprehension, some students from different anxiety levels $(\mathrm{N}=3)$ mentioned in their interviews that lack of vocabulary made them felt anxious to speak English in online English class. Students who were lacking in vocabulary repertoire felt anxious to communicate as speakers during online English class since they were afraid that the meaning which was supposed to be delivered couldn't be understood fully by audiences. This triggered students' anxiety due to communication apprehension as they were afraid that their classmates and teacher would misunderstand their speeches. On the other hand, four students ranging from Relaxed, Mildly Anxious, Anxious, and Very Anxious level mentioned that lack of knowledge of arranging sentences using correct grammar made them felt anxious to speak, it could be inferred that the students considered that to communicate in English they had to use perfect grammar when they couldn't fulfill this expectation, they felt anxious to speak as they assumed that their audiences wouldn't understand. Furthermore, the lack of proper pronunciation mentioned by Dhifa-R as a speaking anxiety' factor. She was afraid of not being able to identify words that have been said by her teacher due to unfamiliar pronunciation. Moreover, thoughts misrepresenting was also mentioned by Rina-MA as the source of speaking anxiety as it contributes to the creation of communication apprehension. She was afraid that the sentences she has made in her mind couldn't be delivered maximally in the target language. In addition, the trigger that was also mentioned as the source of communication 
apprehension was inappropriate pronunciation. Intan-A was anxious if her sentences were not understood by her audience as they caught the wrong meaning from the wrong pronunciation. The last source mentioned was lack of IT knowledge and was donated by Dhifa, the relaxed-level student. Students need to be prepared for any minor to major problems in running the app since it would certainly distract students' concentration during speaking performances which led to failure to make others understand or understand people's sayings.

\section{Test Anxiety}

In addition, the other factor found as the inter-lingual factor is test anxiety. Both data (interviews and reflective journals) showed that the highly mentioned source for test anxiety was inappropriate pronunciation, then followed by lack of preparation. Specifically, inadequate proper pronunciation made Rina-MA and Dwi-VA spell English words incorrectly. They were anxious of getting a low mark if their sentences were not understood by their examiner (teacher) since the teacher caught the wrong meaning from the wrong pronunciation. Moreover, Dwi-VA suggested that practice harder certainly helped to reduce anxiety. However, it should be underlined that it only helped to reduce, and not to get rid of speaking anxiety.

\section{The Role of Inter-Lingual Factors on Arising Students' Speaking Anxiety in Online EFL Classroom}

\section{Communication Apprehension}

As a part of inter-lingual, communication apprehension has developed to some new kind of triggers. To begin with, Qonitah-VR was anxious if she couldn't answer questions related to the material due to the teacher's teaching habit. As the teacher spoke too fast, she couldn't catch the words that her teacher said. This source later be identified as teacher's teaching habit. The other inter-lingual issue that contributed to communication apprehension was the bad internet connection. There were three out of five students (Qonitah-VR, Dhifa-R, Intan-A) who claimed this factor negatively affected their speaking. They felt anxious if their speaking performance in the target language couldn't be understood by audiences since their audiences heard incomplete utterances due to a bad internet connection, hence the exact meaning couldn't be delivered. Furthermore, the other factor affiliated with communication apprehension is fear of being constantly monitored during speaking activity in an online class, the claim was stated by a very anxious student, Dwi. She was shy to turn on her webcam as she assumed that the teacher and other students would constantly monitor her actions. This source later be identified as switching on the webcam. The other emerging code that is affiliated with communication apprehension is the error device, which was claimed by Dhifa-R and Dwi-VA. Dhifa was anxious that her sayings couldn't be understood completely for being cut because the virtual meeting up was crash suddenly, while Dwi was afraid for not being able to catch the others saying since the app was closed suddenly. Moreover, 
the last source is the limited internet balance which was claimed by relaxed-level student. Dhifa. she was anxious about being cut at any time due to run out of internet balance.

\section{Fear of Negative Evaluation}

Furthermore, fear of negative evaluation also contributed as an inter-lingual factor. There were three points of inter-lingual issues that were found as part of the fear of negative evaluation, those were fear of being laughed at, fear of being scolded, and shy personality. In specific, four out of five students based on their interviews' results, starting from relaxed-level, mildly-anxious level, anxious-level, and veryanxious level, were anxious if they speak incorrectly, their classmates would consider it as a funny thing and made a joke of it. Furthermore, one of the students from a mildly anxious level donated the other emerging code of this kind of factor. Rina in her interview section claimed that she was anxious to speak since she was afraid that she would be scolded by her teacher because of making mistakes in speaking. In addition, the last-mentioned issue in fear of negative evaluation is the shy personality which was mentioned by Dwi. In specific, anxious students tend to have attention divided if they exaggeratedly centred their concern on negative evaluation of others instead of focusing on their task. It happened to Dwi as the focal point of the feeling of anxiety to speak was located at her assumption that her classmates would negatively evaluate the way a shy person behaves.

To summarize, this research revealed that in term of manifestation, some categorical factors which contribute in online learning setting has upgraded to be different from conventional learning setting. This similarity of factors' upgrade's presence is also found in Kaisar \& Chowdhury's (2020) research finding, despite the varieties of the manifestations are different. Moreover, based on both categorizations of interviews and reflective journals' results, the researcher found that some factors of speaking anxiety were divided into two kinds of emerging categories, those are intra-lingual factors and inter-lingual factors. The following explanations are the discussion of the findings.

\section{Communication Apprehension}

Most students $(\mathrm{N}=4)$ claimed that their speaking anxieties were influenced by the communication apprehension factor, which contradicting Akkakoson's (2016) finding which claimed that test anxiety became the most frequent factor to appear than communicative apprehension. Specifically, this factor appeared on students whether in the form of intra-lingual or inter-lingual factor, or even both of them. Furthermore, compiled from interviews and reflective journals' interpretation of students, the researcher found that the recall of communication apprehension in form of intra-lingual was mainly influenced by such insufficient knowledge and skills, to be exact, lack of vocabulary, lack of proper grammar, unfamiliar pronunciation, lack of IT knowledge, misrepresenting thought, and inappropriate use of vocabulary. This division of communication apprehension was experienced 
by the students of relaxed level (Dhifa), mildly-anxious level (Rina), anxious level (Intan), very-anxious level (Dwi). On other hand, the recall of communication apprehension in the term of inter-lingual was mainly influenced by bad internet connection, teacher's teaching habit, being monitored online, limited internet balance, and device problems. These inter-lingual reasons were compiled from the claims of the very-relaxed student (Qonitah), relaxed student (Dhifa), mildly anxious student (Rina), and anxious student (Intan). In this research teaching habit was the most mentioned source of communication apprehension, make it the most threatening source. In contrast, Yaniafari and Rihardini (2021) in their research found that learners felt less nervous about teacher's teaching habits in online learning. However, even though both emerging categorical factors have upgrades on some sources, the researcher found that the members of communication apprehension that developed into new manifestation due to learning environment's shifting have mainly happened in the scope of the inter-lingual source.

\section{Test Anxiety}

On the other hand, the sources of test anxiety found in this research came only from the inside triggers of students. Implying that test anxiety is more related to intralingual one since it has specific sources to be affiliated with. Based on the interview and reflective journal's results of Rina (mildly anxious) and Dwi (very anxious), the sources of this categorical factor have been created as the result of inappropriate pronunciation, rarely practice, and lack of preparation. This finding is rather supporting Naudhani, Wu, \& Naudhani's (2018) analogical example where students put hopes and beliefs to speak as perfectly as possible. Specifically, it can be inferred that there is no significant impact of online learning setting on the upgrade on the source of test anxiety.

\section{Fear of Negative Evaluation}

In congruence with the test anxiety factor, only inter-lingual sources have also contributed to the creation of fear of negative evaluation factors. The sources that have been classified as inter-lingual were the sources that always appeared in the fear of negative evaluation. Various sources have been interpreted from the students' statements. Dhifa (relaxed), Intan (anxious), and Dwi (very anxious) mentioned that fear of being laughed at is the factor that arouses their anxiety. Additionally, Dwi (very anxious) also stated that her shy personality was the reason she felt anxious. This is in line with Abdurahman \& Rizqi (2020) which suggested that students that anxious about negative evaluation tend to mind the business that is not related to the task. Moreover, Rina (mildly anxious) stated that her anxiety in speaking was provoked by fear of being scolded. This finding supports Naudhani, $\mathrm{Wu}, \&$ Naudhani's (2018) claim that it happens as the result of dread of getting a low score on the task, as they consider that academic score will affect their future. Specifically, the researcher found that there are no new manifestations of sources related to fear of negative evaluation factors due to the shifting of learning's setting. 
In conclusion, based on the explanation above, the most common factor that contributed to the arousal of the students' speaking anxiety is communication apprehension, which is claimed by all of the students from five anxiety levels. On the other hand, the least factor that involved as the reason for speaking anxiety is test anxiety, which is chosen by only two students from two different levels (very anxious and mildly anxious).

\section{CONCLUSION}

In summary, the frequently appeared sources in Communication apprehension are unfamiliar pronunciation, lack of proper grammar, lack of vocabulary, inappropriate vocabulary, misrepresenting thought, limited internet balance, bad internet connection, teacher speaks too fast, inappropriate pronunciation, lack of IT mastery, switching on webcam, phone's bug, and error device. Furthermore, test anxiety was mainly triggered by inappropriate pronunciation, rarely practice, and lack of preparation. Additionally, fear of negative evaluation was influenced by fear of being laughed at, shy personality, and fear of being scolded. However, this research found that there is no new categorical factor since all of the factors in both interviews and reflective journals can be classified to the existing categorical factors adopted from Horwitz, Horwitz, \& Cope (1986). These sources/triggers/issues affiliated with each major categorical factor can be classified whether to interlingual or intra-lingual or both of them. In specific, based on the source, the categorical factors that appeared as intra-lingual factors are communication apprehension and test anxiety, while inter-lingual factors are communication apprehension and fear of negative evaluation. This means that communication apprehension happened in both intra-lingual and inter-lingual backgrounds. Furthermore, the categorical factors produce new manifestations due to the shifting of learning setting happened only in the communication apprehension category, such as insufficient technological mastery (intra-lingual), bad internet connection (inter-lingual), being monitored through online (inter-lingual), limited internet balance (inter-lingual), and device problems (inter-lingual).

\section{REFERENCES}

Abdurahman, N. H., \& Rizqi, M. A. (2020). Indonesian students' strategies to cope with foreign language anxiety. TESOL Journal.

Akkakoson, S. (2016). SPEAKING ANXIETY IN ENGLISH CONVERSATION CLASSROOMS AMONG THAI STUDENTS. Malaysian Journal of Learning and Instruction: Vol. 13, 63-82.

Bollinger, A. S. (2017). FOREIGN LANGUAGE ANXIETY IN TRADITIONAL AND DISTANCE LEARNING FOREIGN LANGUAGE CLASSROOMS. Lynchburg, VA: Liberty University.

Chou, M.-H. (2018). Speaking Anxiety and Strategy Use for Learning English as a Foreign Language in Full and Partial English-Medium Instruction Contexts. TESOL QUARTERLY Vol. 52, No. 3, 611-633. 
Daud, A., Ras, F., Novitri, \& Audia, C. P. (2019). Factors Contributing to Speaking Anxiety: A Case Study of Pre-Service English Teachers. Journal of Educational Sciences Vol. 3 No. 3, 412-422.

Etikan, I. (2016). Comparison of Convenience Sampling and Purposive Sampling. American Journal of Theoretical and Applied Statistics, 5 (1); 1-2.

Grant, S., Huang, H., \& Pasfield-Neofitou, S. (2013). Language Learning in Virtual Worlds: The Role of Foreign Language and Technical Anxiety. Journal of Virtual World Research, Vol. 6, No.1, 1-9.

Heigham, J., \& Croker, R. A. (2009). Qualitative Research in Applied Linguistics: A Practical Introduction. London: Palgrave Macmillan.

Horwitz, E. K., Horwitz, M. B., \& Cope, J. (1986). Foreign Language Classroom Anxiety. The Modern Language Journal, Vol. 70, No. 2 (Summer, 1986), pp. 125-132.

Irawan, A. W., Dwisona, \& Lestari, M. (2020). Psychological Impacts of Students on Online Learning During the Pandemic COVID-19. KONSELI: Jurnal Bimbingan dan Konseling (E-Journal) 07 (01), 53-60.

Kaisar, M. T., \& Chowdhury, S. Y. (2020). Foreign Language Virtual Class Room: Anxiety Creator or Healer? English Language Teaching; Vol. 13, No. 11, 130-139.

Majid, F. A., Sharil, W. N., Luaran, J. E., \& Nadzri, a. F. (2012). A Study on the On-Line Language Learning Anxiety among Adult Learners. International Journal of e-Education, e-Business, e-Management and e-Learning, Vol. 2, No. 3, 187-192.

McIntyre, P. D., \& Gardner, R. C. (1991). Investigating Language Class Anxiety Using the FocusedEssay Technique. The Modern Language Journal, 298304.

Naudhani, M., Wu, Z., \& Naudhani, S. (2018). Exploring the Factors of Foreign Language Anxiety Among Chinese Undergraduate English Majors and NonEnglish Majors. International Journal of English Linguistics; Vol. 8, No. 5, 142-150.

Pichette, F. (2009). Second Language Anxiety and Distance Language Learning. Foreign Langauge Annals, Vol. 42, No. 1, 77-94.

Yaniafari, R. P., \& Rihardini, A. A. (2021). FACE-TO-FACE OR ONLINE SPEAKING PRACTICE: A COMPARISON OF STUDENTS' FOREIGN LANGUAGE CLASSROOM ANXIETY LEVEL. JEELS (Journal of English Education and Linguistics Studies), 8(1), 49-67.

Yasuda, T., \& Nabei, L. (2018). Effects of Coping Strategies on Language Anxiety of Japanese EFL Learners: Investigating Willingness to Communicate. Journal of Language Teaching and Research, Vol. 9, No. 5, pp. 905-915.

Yulia, H. (2020). Online Learning to Prevent the Spread of Pandemic Corona Virus in Indonesia. ETERNAL (English Teaching Journal), 48-56. 